\title{
Chloral hydrate disrupts mitosis by increasing intracellular free calcium
}

\author{
GRETA M. LEE \\ Department of \%oology, Duke University, Durham, NC 27706, LSA \\ JIM DIGUISEPPI*, GOVIND M. GAWDI and BRIAN HERMAN \\ Department of Amatomy, University of Vorth Carolina, Chapel Hill, IC 275/4, LSA \\ * Present address: Orgenon-Technica, Research Triangle Park, NC 27709, USA
}

\section{Summary}

In examining how chloral hydrate affects mitosis, we found that extracellular application of $0.1 \%$ chloral hydrate produced an abrupt rise in cytosolic free $\mathrm{Ca}^{2+}$. Digitized fluorescence microscopy of Fura-2-loaded, mitotic and interphase $\mathrm{PtK}$ cells revealed that $\mathrm{Ca}^{2+}$ rose $15 \mathrm{~s}$ after chloral hydrate application, peaked within $1 \mathrm{~min}$ at a concentration two- to sevenfold above the basal level and then slowly dropped. Bathing cells in $0.1 \%$ chloral hydrate caused metaphase spindles to shorten, starting in 1-2 $\mathrm{min}$, and inhibited spindle elongation without affecting chromosome-to-pole movement during anaphase, as determined by phase-contrast observation of living cells. Spindle elongation and chromosome movement were unaffected by intracellular injection of $7.5 \%$ chloral hydrate. Extensive mitotic microtubule breakdown occurred after cells were bathed for $7 \mathrm{~min}$ in $0.1 \%$ chloral hydrate, while interphase microtubules were unaffected as determined by immunofluorescence. The chloral hydrate-induced microtubule breakdown and metaphase spindle shortening were prevented by $10 \mathrm{mM} \cdot \mathrm{CoCl}_{2}$, which has previously been shown to block $\mathrm{Ca}^{2+}$ influx and to stabilize microtubules in vitro. These results imply that disruption of mitotic spindle function and structure by chloral hydrate is due to a rise in cytosolic free $\mathrm{Ca}^{2+}$, and also indicate that mitotic microtubules are more $\mathrm{Ca}^{2+}$.labile than interphase microtubules.

Key words: anaesthetic, spindle structure, cobalt chloride.

\section{Introduction}

Chloral hydrate is a sedative-hypnotic drug and a metabolite of the widely used industrial chemical, trichloroethylene. It is also a known mutagen (Russo et al. 1984; Kafer, 1986), which acts by disrupting mitosis (Mercer \& Morris, 1975; Ates \& Sentein, 1978; Mole-Bajer, 1967). The disruption is due to mitotic spindle collapse as determined by electron microscopy of cells bathed in dilute solutions of chloral hydrate (Mole-Bajer, 1967). When applied in a very narrow concentration range, chloral hydrate inhibits spindle clongation without affecting chromosome-to-pole movement during anaphase in grasshopper spermatocytes (Ris, 1949).

Journal of Cell Science 88, 603-612 (1987)

Printed in Great Britain (C) The Company of Biologists Limited 1987
The effects of chloral hydrate on mitosis may involve $\mathrm{Ca}^{2+}$ regulation. Other general anaesthetics, such as $\mathrm{C}_{5}$ to $\mathrm{C}_{10}$ alcohols and chloroform, cause an increase in intracellular free $\mathrm{Ca}^{2+}$ (Vassort et al. 1986). The possibility that chloral hydrate raises intracellular $\mathrm{Ca}^{2+}$ was first proposed by Dunlap (1977) to explain how chloral hydrate produces deciliation of Paramecium caudatum. The rise in intracellular $\mathrm{Ca}^{2+}$ might occur via inhibition of the plasma membrane $\mathrm{Ca}^{2+} / \mathrm{Mg}^{2+}$. ATPase, since chloral hydrate reversibly inhibits this enzyme in vitro (Bergesse et al. 1983). This ATPase functions to pump $\mathrm{Ca}^{2+}$ out of the cell, thus finetuning the intracellular free calcium concentration (Carafoli \& Penniston, 1985; Schatzmann, 1982). Vasopressin and insulin, agents that are known to cause an elevation in intracellular calcium (Berridge \& 
Irvinc, 1984; Lemasters et al. 1987), inhibit this plasma membrane calcium pump (Lin et al. 1983; Pershadsingh \& McDonald, 1981).

Alterations in levels of cytosolic free calcium may be involved both in microtubule lability and in the regulation of mitosis. Microtubules in intact cells (Kiehart, 1981; Izant, 1983), in isolated spindles (Salmon \& Segall, 1980; Salmon, 1982) and assembled in vitro (Marcum et al. 1978; Rebhun et al. 1980) are labile to micromolar concentrations of $\mathrm{Ca}^{2+}$. The rate of microtubulc breakdown is directly related to $\mathrm{Ca}^{2+}$ concentration. Physiologically elevated $\mathrm{Ca}^{2+}$ levels have been suggested as being involved in microtubule turnover (Fuller \& Brinkley, 1976; Marcum et al. 1978; Salmon \& Segall, 1980). This suggestion is given credence by the recent finding of a sudden, transient rise in calcium to $500-800 \mathrm{nM}-\mathrm{Ca}^{2+}$ at the onset of anaphase (Poenie et al. 1986). This finding also emphasizes the role of calcium in the regulation of mitosis. Further evidence for the importance of $\mathrm{Ca}^{2+}$ in the metaphase-anaphase transition is that metaphase $\mathrm{PtK}$ cells enter anaphase more rapidly after injection of $1-10 \mu \mathrm{M}-\mathrm{CaCl}_{2}$ (Izant, 1983) and that the metaphase-anaphase transition is prevented by blocking $\mathrm{Ca}^{2+}$ influx (Hepler, 1985). Calcium may also be involved in local regulation within the spindle, since the spindle contains many vesicles that sequester calcium (Hepler \& Wolniak, 1984). In addition, the distribution of calcium (Ratan et al. 1986) and of calmodulin (De Mey et al. 1980; Vantard et al. 1985) within the spindle changes as the cell progresses through mitosis.

In the present study, we found a rapid rise in intracellular free calcium in $\mathrm{PtK}$ cells following exposure to chloral hydrate, by using the fluorescent $\mathrm{Ca}^{2+}$ indicator, Fura-2, and digitized fluorescence microscopy. Fura-2 was particularly useful for our purpose of studying a drug with unknown, possibly multiple, effects on the cell since it is well-established as a $\mathrm{Ca}^{2+}$ indicator (Grynkiewicz et al. 1985; Lemasters el al. 1987; Poenic et al. 1985, 1986; Ratan et al. 1986; Roe et al. 1987; Wier et al. 1987) and is fairly insensitive to changes in $\mathrm{pH}$ and $\mathrm{Mg}^{2+}$ within the physiological range (Grynkicwicz et al. 1985; Poenie et al. 1985). Demonstrating the role of this rise in calcium in producing the observed effects of chloral hydrate on mitosis is less straightforward. Several approaches were used. (1) Extracellular, but not intracellular, application of chloral hydrate inhibited spindle elongation, which implies that chloral hydrate was not acting directly on the spindle but via an intermediate such as $\mathrm{Ca}^{2+}$. (2) The pattern of chloral hydrateinduced microtubule breakdown, revealed by tubulin immunofluorescence, compared favourably with $\mathrm{Ca}^{2+}$. induced microtubule breakdown observed in previous studies. (3) Treatment with $\mathrm{CoCl}_{2}$, which has been shown to inhibit $\mathrm{Ca}^{2+}$ influx (Kohlhardt et al. 1973) and to stabilize microtubules against $\mathrm{Ca}^{2+}$ (Wallin et al. 1977), maintained spindle structure in the presence of chloral hydrate.

\section{Materials and methods}

PtK cells, cell lines derived from rat kangaroo kidney epithelium (PtK1 from American Type Culture Collection, Rockville, MD; and PtK2, a gift from M. Berns, University of California, Irvine) were maintained in tissue culture medium: Ham's F12 nutrient mixture supplemented with $10 \%$ foetal calf serum (GIBCO, Grand Island, NY) and $0.05 \mathrm{mg} \mathrm{ml}^{-1}$ neomycin sulphate or $0.1 \mathrm{mg} \mathrm{ml}^{-1}$ kanamycin (Sigma, St Louis, MO). For anaphase rate measurements and $\mathrm{Ca}^{2+}$ determinations, cells were plated 2-6 days prior to use in chambers assembled from $25 \mathrm{~mm}$ round coverslips attached with silicone vacuum grease to $5 \mathrm{~mm}$ high glass cylinders (Rappaport, 1986). Anaphase rate measurements were done with cells in tissue culture medium plus $50 \mathrm{~mm}$. Hepes (Sigma) covered with a thin layer of mineral oil (Squibb). Spindle structure experiments and $\mathrm{Ca}^{2+}$ measurements were done with cells in saline $\mathrm{G}(140 \mathrm{~mm}-\mathrm{NaCl}$, $5 \mathrm{~mm}-\mathrm{KCl}, 6 \mathrm{~mm}$-glucose, $0.6 \mathrm{~mm}-\mathrm{MgSO}_{4}, 1.1 \mathrm{~mm}-\mathrm{CaCl}_{2}$, $1 \mathrm{~mm}-\mathrm{Na}_{2} \mathrm{HPO}_{4}, 1 \mathrm{~mm}-\mathrm{KH}_{2} \mathrm{PO}_{4}$ ) at $34-37^{\circ} \mathrm{C}$. The phosphates in saline $\mathrm{G}$ were replaced with $25 \mathrm{~mm}$-Hepes for the $\mathrm{CoCl}_{2}$ treatments.

An inverted Zeiss microscope with $40 \times$ phase-contrast optics (numerical aperture: of objective, 0.75 ; of condenser, $0 \cdot 9$ ) was used for the anaphase rate measurements. Temperature was maintained at $34-35^{\circ} \mathrm{C}$ with a Sage air-curtain incubator and monitored with a Tele-Thermometer (Yellow Springs Instrument Co., Inc.). Kinetochore separation and spindle elongation were measured directly using an ocular micrometer. At the onset of anaphase, chloral hydrate (Fisher Scientific) was applied either extracellularly in tissue culture medium or by pressure microinjection in $100 \mathrm{~mm}$-Pipes, $0 \cdot 1 \mathrm{mM}-\mathrm{MgCl}_{2}$ (MI buffer).

The equipment and procedure for the $\mathrm{Ca}^{2+}$ measurements have been described (DiGuiseppi et al. 1985; Lemasters et al. 1987). Briefly, a video digitizing system was used to acquire pixel-by-pixel averaged fluorescence intensities of Fura-2-loaded cells observed at $>450 \mathrm{~nm}$ when excited at 340 and $380 \mathrm{~nm}$. After correction for background and autofluorescence, the ratio of fluorescence emission intensity obtained at the two excitation wavelengths $(340 \mathrm{~nm}$ divided by $380 \mathrm{~nm}$ ) was computed for each pixel. The $\mathrm{Ca}^{2+}$ concentration was computed from the mean pixel ratio for the cell using a standard curve generated by measurement of Fura-2 pentapotassium salt, Ca-EGTA buffers of known $\mathrm{Ca}^{2+}$ concentration. It is clear that the intracellular environment is different from that of our standard Fura-2 solutions, and calculations by others (Poenie et al. 1986) show that differences between the two environments can lead to a $15 \%$ error in the estimation of $\mathrm{Ca}^{2+}$ concentrations in cells. However, we are concerned with relative and not absolute changes, and recognize that our values may be in error by $15 \%$. Fura-2 pentapotassium salt (Molecular Probes, Junction City, OR) ( $1 \mathrm{mM}$ in MI buffer) was nicroinjected into the PtK cells for measurement of intracellular free $\mathrm{Ca}^{2+}$. The microinjected interphase and mitotic cells were held at room temperature 
and $4^{\circ} \mathrm{C}$, respectively, for approximately $2-4 \mathrm{~h}$ and then warmed to $34^{\circ} \mathrm{C}$ for $2-10 \mathrm{~min}$ prior to measurement. The mitotic cells were kept cold to stop their progress through mitosis while they were being transported from the laboratory where the microinjections were done to the laboratory where the $\mathrm{Ca}^{2+}$ measurements were made. Measurements were done only on cells with uniformly fluorescent cytoplasm that were typical of the majority in size and had either a single, round nucleus or a bipolar spindle.

Spindle structure was examined by immunocytochemistry after several treatments: chloral hydrate, $\mathrm{CoCl}_{2}, \mathrm{CoCl}_{2}$ plus chloral hydrate, and nocodazole after $\mathrm{CoCl}_{2}$ or $\mathrm{CoCl}_{2}$ plus chloral hydrate. For the chloral hydrate treatment, $0.1 \%$ chloral hydrate in Hepes-buffered tissue-culture medium or in saline $\mathrm{G}$ was applied to the $\mathrm{PtK}$ cells on coverslips for $10 \mathrm{~min}$ at $37^{\circ} \mathrm{C}$. For the $\mathrm{CoCl}_{2}$ treatment, cells were incubated $11 \mathrm{~min}$ at $37^{\circ} \mathrm{C}$ in $10 \mathrm{~mm}-\mathrm{CoCl}_{2}$. For $\mathrm{CoCl}_{2}$ followed by chloral hydrate, cells were incubated for $1 \mathrm{~min}$ in $\mathrm{CoCl}_{2}$ at $37^{\circ} \mathrm{C}$ and then $10 \%$ chloral hydrate in $\mathrm{dH}_{2} \mathrm{O}$ was added to the $\mathrm{CoCl}_{2}$-containing buffer to a final concentration of $0.1 \%$ and incubation was continued for an additional $10 \mathrm{~min}$ at $37^{\circ} \mathrm{C}$. For the nocodazole treatment, the cells were rinsed briefly then transferred to $2 \cdot 5 \mu \mathrm{m}$-nocodazole (Sigma) for $10 \mathrm{~min}$ at $37^{\circ} \mathrm{C}$. The coverslips were transferred to $1 \%$ glutaraldehyde in phosphate-buffered saline (PBS) (Osborn $\&$ Weber, 1982) at room temperature for $10 \mathrm{~min}$. All of the following steps were done with PBS at room temperature. After four rinses for $5 \mathrm{~min}$ each, the coverslips were treated for $30 \mathrm{~min}$ in $0.5 \%$ Nonidet P-40 (Sigma), rinsed briefly, treated for $15 \mathrm{~min}$ in $0.5 \mathrm{mg} \mathrm{ml}^{-1} \mathrm{NaBH}_{4}$, rinsed twice for $10 \mathrm{~min}$, and once in $1 \%$ bovine serum albumin (BSA/PBS) for $20 \mathrm{~min}$. Then $25-30 \mu \mathrm{l}$ of $1: 500(\mathrm{v} / \mathrm{v})$ mouse anti- $\alpha$ tubulin and anti- $\beta$-tubulin (Amersham Corp., Arlington, IL) was applied. After a $45-\mathrm{min}$ incubation at $37^{\circ} \mathrm{C}$, the coverslips were rinsed three times for $10 \mathrm{~min}$ in BSA/PBS. Then 25-30 $\mu 1$ of $1: 15(\mathrm{v} / \mathrm{v})$ TRITC-labelled goat anti-mouse affinity-purified IgG (Jackson Immuno Research Lab., Avondale, $P A$ ) was applied followed by a 45-min incubation at $37^{\circ} \mathrm{C}$. After three 10 -min rinses in $\mathrm{BSA} / \mathrm{PBS}$, the coverslips were mounted on slides with a polyvinyl alcohol mounting medium (Osborn \& Weber, 1982) containing $1 \%$ propyl gallate.

Cells were selected for photography using the following criteria: (1) in the desired stage of mitosis (late anaphase or mid to late metaphase), (2) intensely stained, and (3) very flat with both poles in focus. Micrographs were taken using Kodak Technical Pan 2415 film at ASA 80 and processed with Kodak HC110 developer, dilution B for $6 \mathrm{~min}$.

\section{Results}

\section{Effect of chloral hydrate on calcium concentration}

As determined by digitized fluorescence microscopy of Fura-2-loaded cells, intracellular free $\mathrm{Ca}^{2+}$ started to rise within $15 \mathrm{~s}$ and went up $2 \cdot 3$ - to 7 -fold within $1 \mathrm{~min}$ after extracellular application of $0 \cdot 1 \%$ chloral hydrate. Two mitotic cells had a greater than 20 -fold increase in $\mathrm{Ca}^{2+}$. For both mitotic and interphase cells, the $\mathrm{Ca}^{2+}$ then returned to a lower level but had not returned to the baseline level after $12 \mathrm{~min}$. Average values for both mitotic and interphase cells are given in Table 1 . The rise in $\mathrm{Ca}^{2+}$ concentration in response to chloral hydrate is plotted in Fig. 1 for an interphase and a mitotic cell. The rapid rise in $\mathrm{Ca}^{2+}$ in response to chloral hydrate is typical of all cells measured, but the peak concentration and the rate and extent of decrease after reaching the peak concentration were highly variable (Table 1 ). The ratioed image of the chloral hydrate-treated cells revealed an even increase in $\mathrm{Ca}^{2+}$ over the whole cell (not shown). Interphase cells had a higher average basal level of $\mathrm{Ca}^{2+}$ than did mitotic cells (Table 1).

\section{Effect of chloral hydrate on anaphase chromosome movement}

The extracellular application of $0.1 \%$ chloral hydrate at the onset of anaphase greatly inhibited spindle elongation (Fig. 2). The spindles in buffer-injected cells increased in length by an average of $71 \%$, whereas chloral hydrate-bathed cells increased in spindle length by $32 \%$. When chloral hydrate-bathed cells were compared with cells injected with $\mathrm{Ml}$ buffer or chloral

Table 1. The effect of chloral hydrate on intracellular calcium

\begin{tabular}{lcc}
\hline & lnterphase & Mitotic \\
\hline Number of cells & 6 & 7 \\
Baseline concn (nM)* & $164 \pm 17$ & $79 \pm 14$ \\
Peak concn (nM) & $567 \pm 46$ & $724 \pm 132$ \\
Time to peak (s) & $49 \pm 20$ & $49 \pm 5$ \\
Concn at 4 min (nM) & $381 \pm 50$ & $489 \pm 80$ \\
& \\
Values are given as mean \pm standard error. \\
* Concn, Ca ${ }^{2+}$ concentration as determined by digitized \\
fluorescence microscopy of Fura-2-loaded Ptkl cells. \\
\hline
\end{tabular}

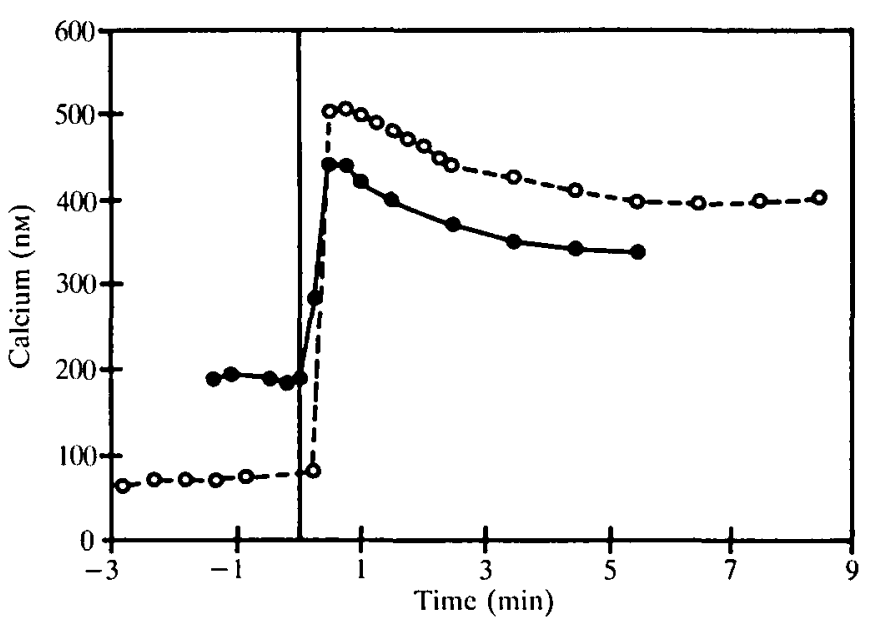

Fig. 1. Time course of $\mathrm{Ca}^{2+}$ concentration in response to $0.1 \%$ chloral hydrate added at 0 time. The $\mathrm{Ca}^{2+}$ concentration was determined by digitized fluorescence microscopy of Fura-2-stained PtKl cells. (O---O) A metaphase cell; (-) an interphase cell. 
hydrate, the difference was statistically significant at the $P<0.01$ level as determined by two-way analysis of variance with repeated measures. However, the injection of $7.5 \%$ chloral hydrate had little effect $(P>0.94$ when compared with the buffer-injected cells). Cytokinesis was unaffected by chloral hydrate.

Chromosome-to-pole movement is plotted in Fig. 3. Since kinctochore separation involves both chromosome-to-pole movement and spindle elongation, any retardation of spindle elongation will also affect kinetochore separation. Therefore, the separation due to spindle elongation has been subtracted from each of the respective curves. The rate of chromosome-to-pole movement after exposure to chloral hydrate, either applied extracellularly or injected, was not significantly different from that in the MI buffer-injected cells $(P>0 \cdot 1$, two-way analysis of variance with repeated measures).

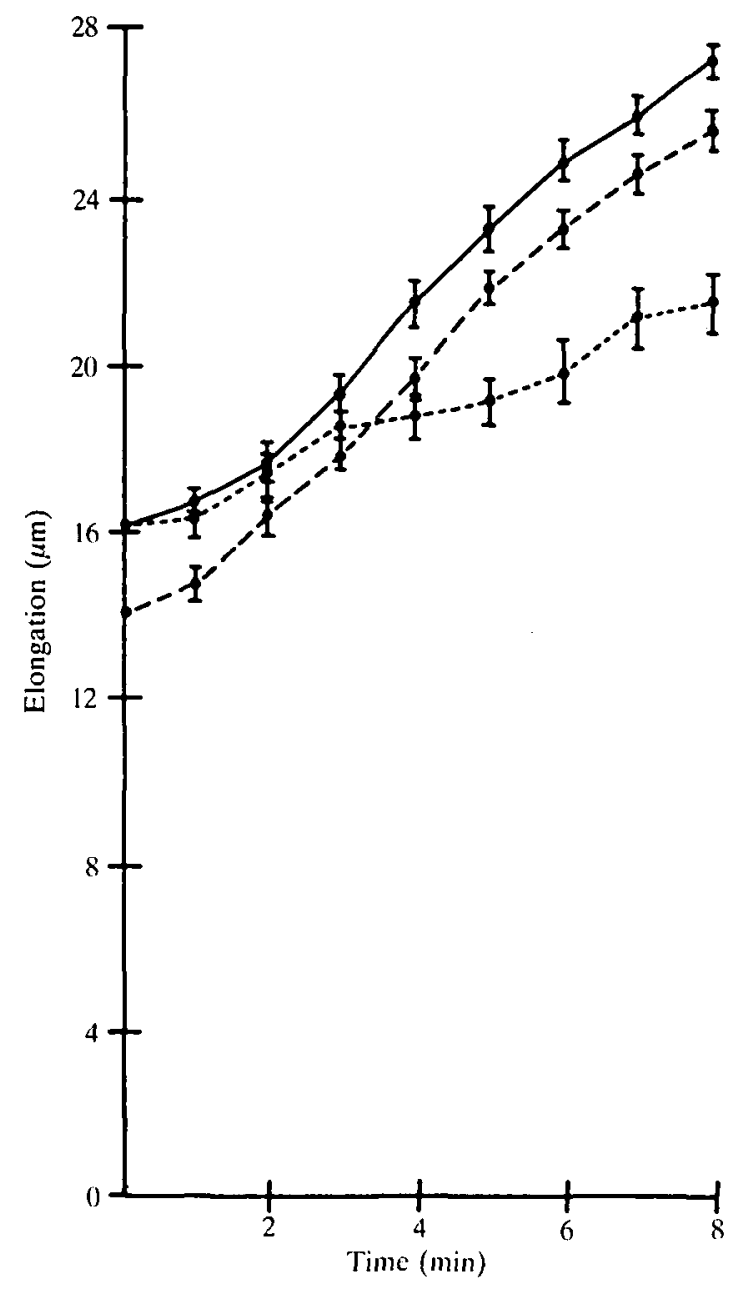

Fig. 2. Anaphase spindle elongation in PtK2 cells after treatment: (-) MI buffer microinjected (10 cells); (--) $7.5 \%$ chloral hydrate microinjected ( 12 cells); (....) extracellular $0 \cdot 1 \%$ chloral hydrate $(7$ cells). All treatments were given at the onset of anaphase. Bars represent standard error.

\section{Effect of chloral hydrate on spindle structure}

As can be seen in Fig. 4 , the effect of $0.1 \%$ chloral hydrate applied extracellularly on anaphase spindle structure after $5 \mathrm{~min}$ involved no apparent decrease in microtubules but interzone and astral microtubules became wavy. The comparatively long astral microtubules seen in Fig. 4B may or may not be due to exposure to chloral hydrate, since astral microtubule length is quite variable in different anaphase cells. By $10 \mathrm{~min}$, astral microtubules had disappeared and there appeared to be some reduction in the number of interzone microtubules.

In living metaphase cells, the spindles started to shorten within 1-2 $\mathrm{min}$ after application of $0.1 \%$ chloral hydrate and continued to shorten for approximately $3 \mathrm{~min}$. As shown by tubulin immunofluorescence (Fig. 5), the astral microtubules became longer during this time period as compared to untreated late metaphase cells, which have uniformly short astral microtubules. By $10 \mathrm{~min}$, astral and interpolar microtubules have mostly disappeared (Fig. 5D). When cells were placed in fresh, chloral hydrate-free tissue-culture medium at $37^{\circ} \mathrm{C}$, spindle structure returned to normal in less than $10 \mathrm{~min}$ (not shown).

\section{Effect of cobalt ions and chloral hydrate on spindle structure}

Pretreatment and the continued presence of $10 \mathrm{~mm}$ $\mathrm{CoCl}_{2}$ prevented the chloral hydrate-induced spindle collapse of metaphase cells (Fig. 6). To determine whether $\mathrm{Co}^{2+}$ was entering the cell and stabilizing

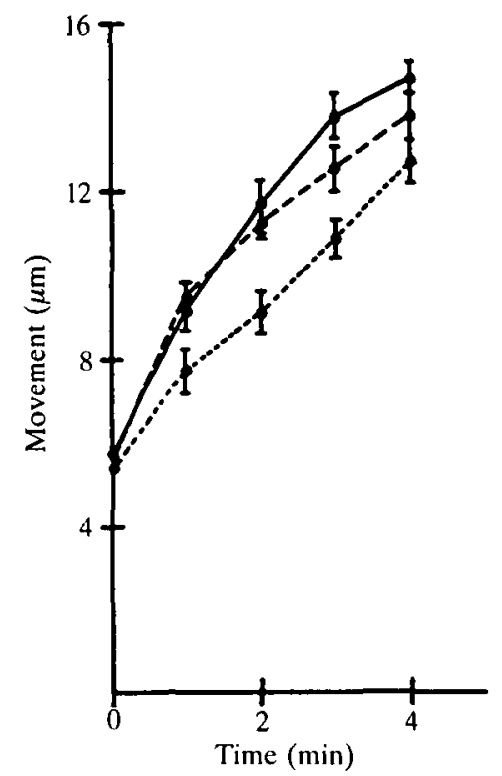

Fig. 3. Anaphase chromosome-to-pole movement in $\mathrm{PtK} 2$ cells after treatment: (-) MI buffer microinjected (10 cells); (--) 7.5\% chloral hydrate-microinjected (12 cells); $(.-.-)$ extracellular $0.1 \%$ chloral hydrate $(7$ cells). All treatments were given at the onset of anaphase. These are the same cells as in Fig. 2. Bars represent standard error. 
microtubules before the addition of chloral hydrate, cells were rinsed prior to the addition of chloral hydrate. In this case, spindle collapse was not prevented (Fig. 6D). In addition, when cells in $10 \mathrm{~mm}$ $\mathrm{CoCl}_{2}$ solution were exposed to $2 \cdot 5 \mu \mathrm{M}$-nocodazole for $10 \mathrm{~min}$, microtubule breakdown was the same as in cells exposed to nocodazole without $\mathrm{CoCl}_{2}$ (Fig. 7).
(Note: cobalt ions stabilize microtubules in zilro against calcium and colchicine (Wallin et al. 1977). Like colchicine, nocodazole depolymerizes microtubules in vivo (DeBrabander et al. 1986)). To determine whether $\mathrm{Co}^{2+}$ entered the cell when chloral hydrate was added, cells were treated with $\mathrm{CoCl}_{2}$ plus chloral hydrate and then exposed to nocodazole. In
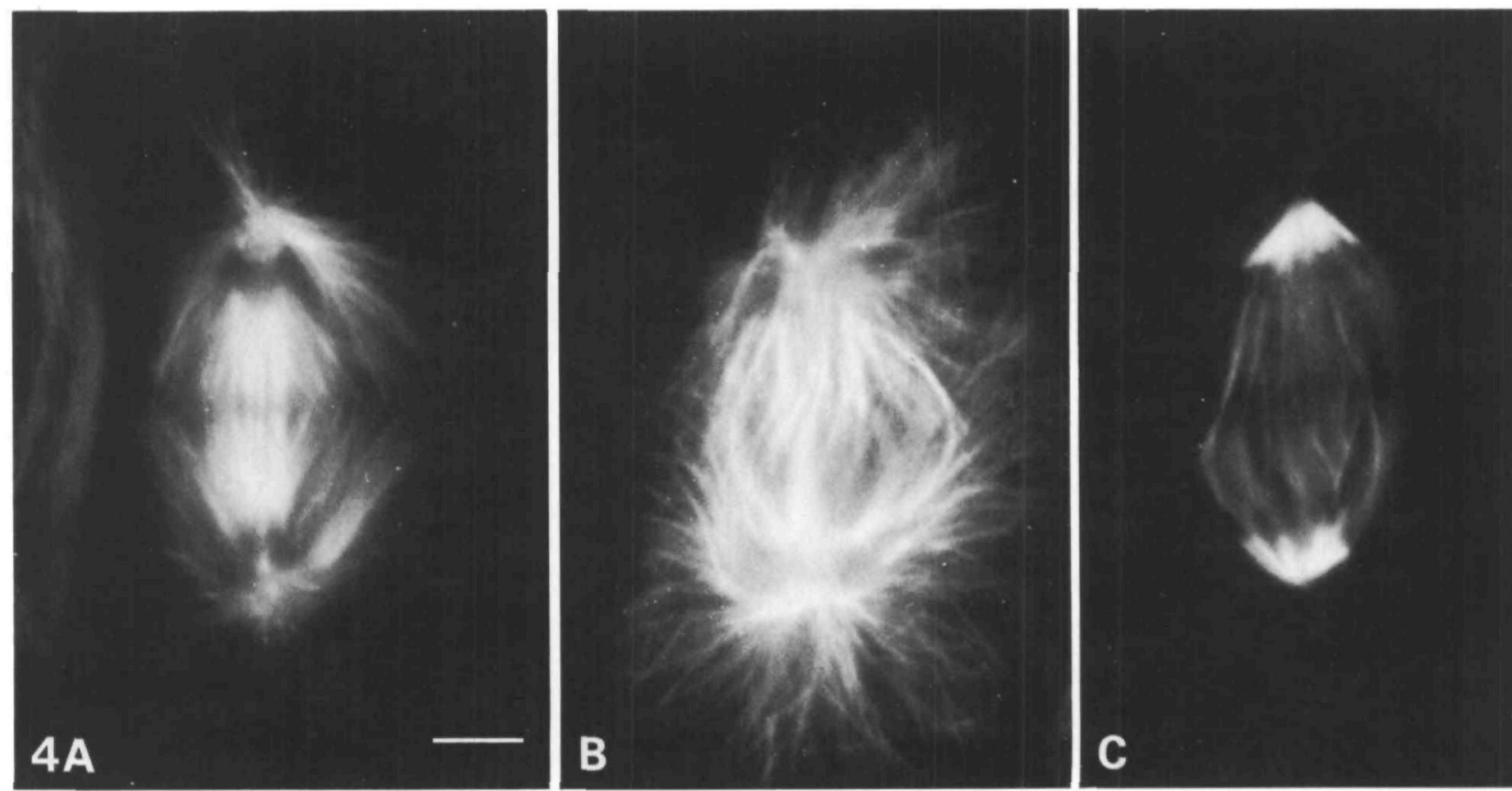

Fig. 4. Effect of $0 \cdot 1 \%$ chloral hydrate on anaphase spindle structure in three different PtKl cells. A. Buffer only; B, after a $5 \mathrm{~min}$ exposure to chloral hydrate; $\mathrm{C}$, after a $10 \mathrm{~min}$ exposure to chloral hydrate. Bar, $5 \mu \mathrm{m}$.
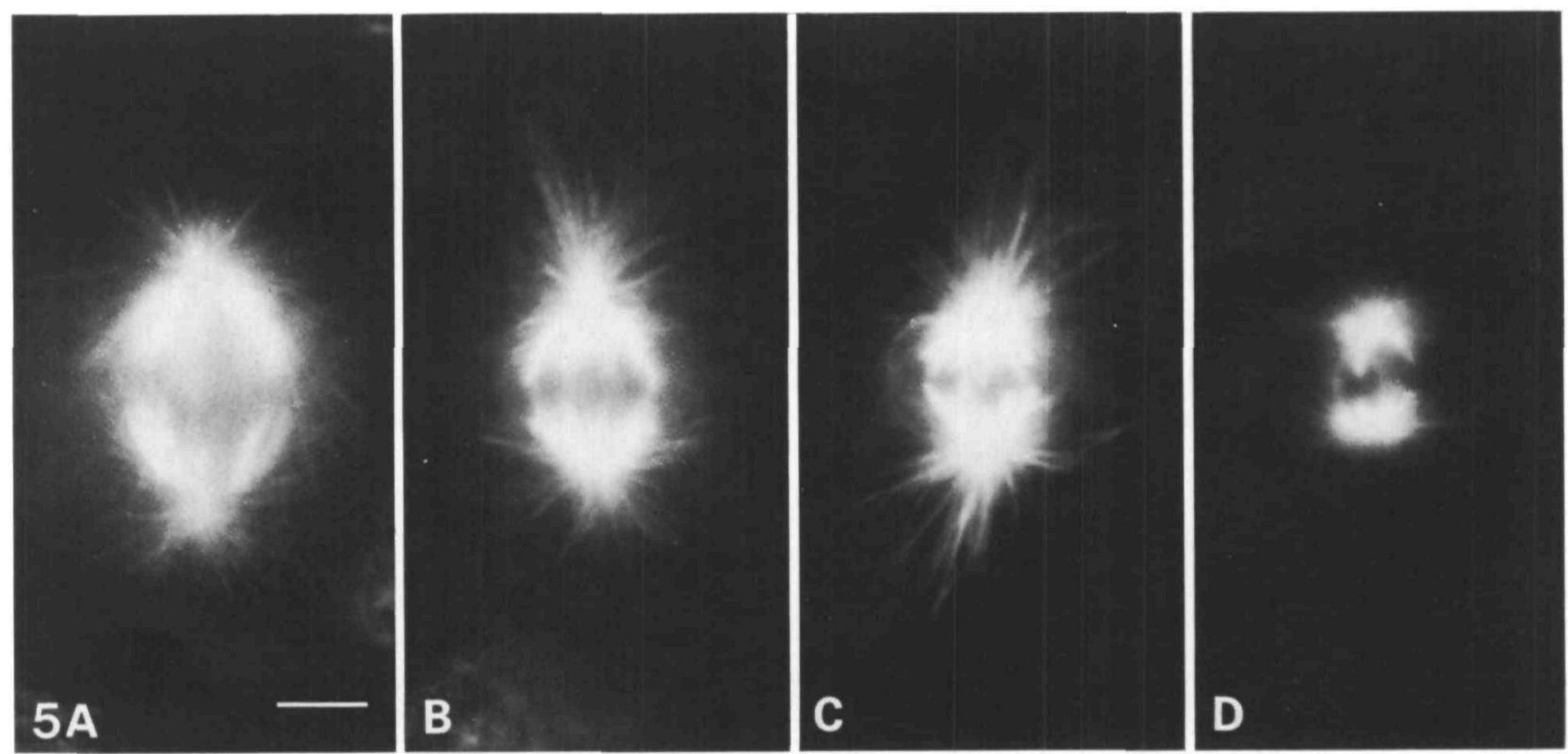

Fig. 5. Effect of $0 \cdot 1 \%$ chloral hydrate on metaphase spindle structure in four different PtKl cells. A. Buffer only; B, after a 2 min exposure to chloral hydrate; $\mathrm{C}$, after a $5 \mathrm{~min}$ exposure to chloral hydrate; $\mathrm{D}$, after a $10 \mathrm{~min}$ exposure to chloral hydrate. Bar, $5 \mu \mathrm{m}$. 

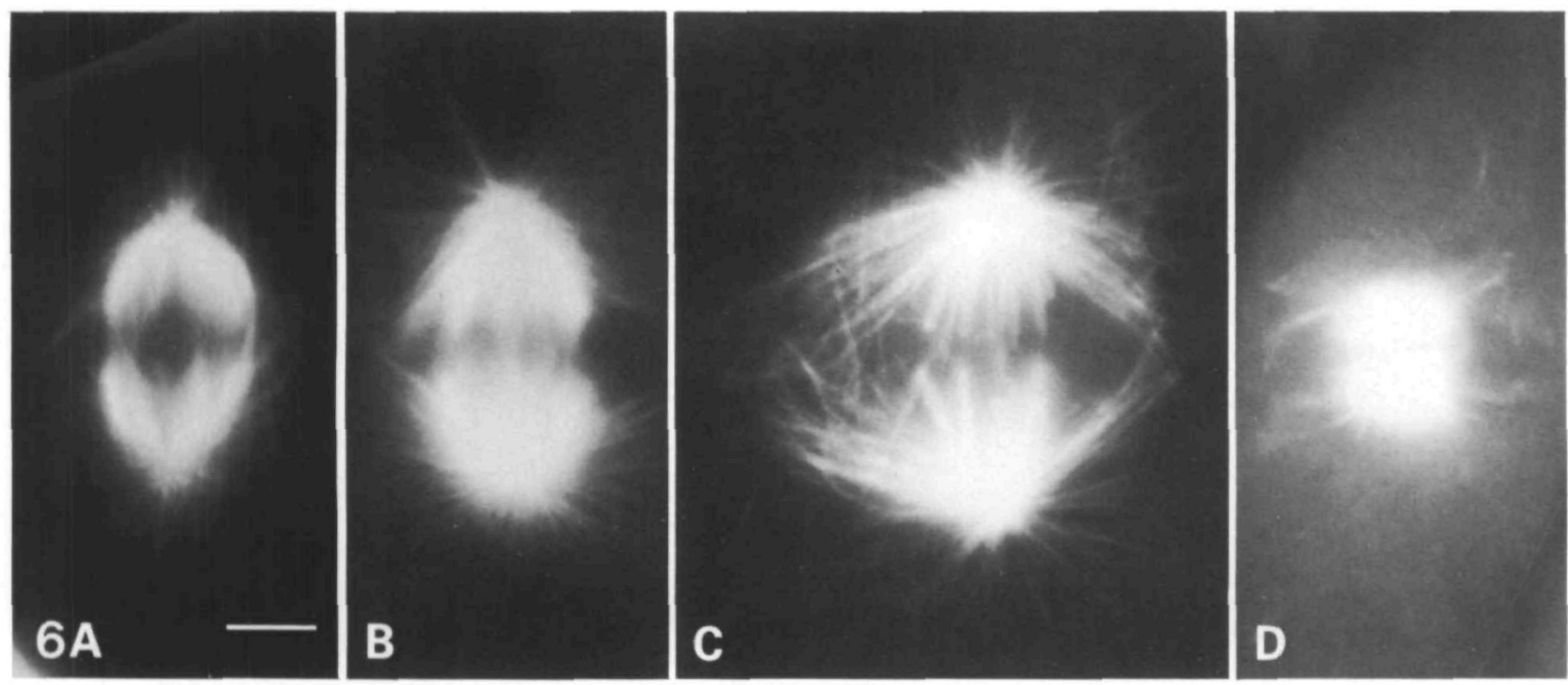

Fig. 6. Effect of $0 \cdot 1 \%$ chloral hydrate counteracted by $10 \mathrm{mM}-\mathrm{CoCl}_{2}$ on metaphase spindle structure in PtK1 cells. A. Buffer only; $\mathrm{B}, 11 \mathrm{~min}$ exposure to $\mathrm{CoCl}_{2} ; \mathrm{C}, 1 \mathrm{~min}$ exposure to $\mathrm{CoCl}_{2}$ followed by 10 min exposure to chloral hydrate plus $\mathrm{CoCl}_{2} ; \mathrm{D}, 1$ min exposure to $\mathrm{CoCl}_{2}$, rinsed and then chloral hydrate for $10 \mathrm{~min}$. Bar, $5 \mu \mathrm{m}$.
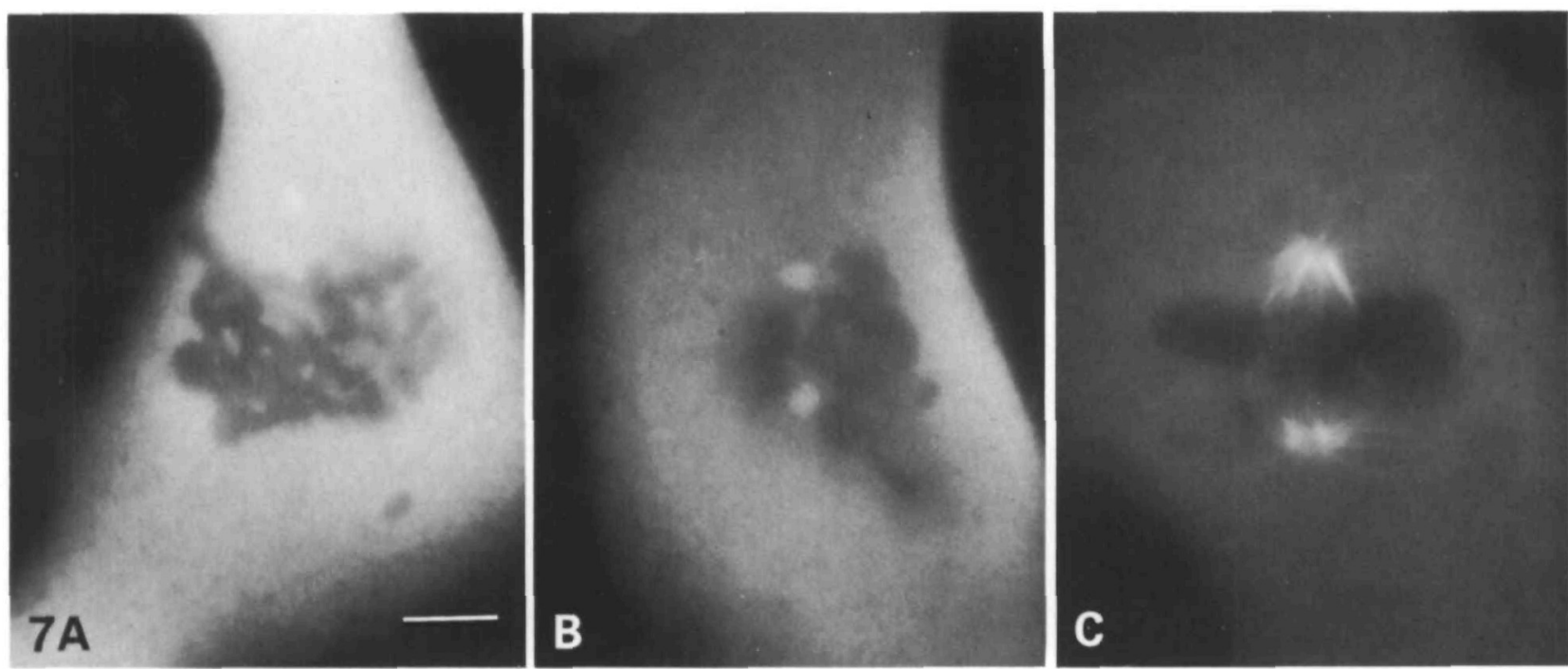

Fig. 7. Stabilization of microtubules against $2 \cdot 5 \mu \mathrm{m}$-nocodazole by $\mathrm{Co}^{2+}$ in mitotic PtK 1 cells. A. Nocodazole for $10 \mathrm{~min}$; $\mathrm{B}, 1 \mathrm{~min}$ exposure to $\mathrm{CoCl}_{2}$ followed by 10 min exposure to nocodazole plus $\mathrm{CoCl}_{2} ; \mathrm{C}, 1$ min exposure to $\mathrm{CoCl}_{2}, 10 \mathrm{~min}$ exposure to chloral hydrate plus $\mathrm{CoCl}_{2}$, brief rinse, and then $10 \mathrm{~min}$ in nocodazole.

these cells, some microtubules were preserved (Fig. 7C). A summary of the effect on microtubules of the various drug treatments is given in Table 2 .

\section{Effect of chloral hydrate on interphase cells}

Exposure to chloral hydrate for up to $10 \mathrm{~min}$ did not affect interphase cell microtubules as determined by immunofluorescence (not shown), but the nuclear envelope and nucleolus became very refractile as seen by phase-contrast microscopy.

\section{General observations}

In both metaphase and interphase cells treated with $0.1 \%$ chloral hydrate applied extracellularly, the structure of the mitochondria became altered: they appeared as small dots instead of as the usual thin lines seen by phase-contrast microscopy $(100 \times$ objective, numerical aperture of 1.3). Such alterations in structure are frequently seen in mitochondria damaged by elevated levels of calcium (Carafoli, 1982). Observations of living cells showed that saltatory motion continued in cells bathed in $0.1 \%$ chloral hydrate. 
Table 2. Summary of the effects of chloral hydrate, $\mathrm{COCl}_{2}$ and nocodazole on microtubules in PtKI cells

\begin{tabular}{|c|c|c|}
\hline & $\begin{array}{l}\text { Mitotic } \\
\text { microtubules }\end{array}$ & $\begin{array}{l}\text { Interphase } \\
\text { microtubules }\end{array}$ \\
\hline Control & +++ & $+t+$ \\
\hline Chloral hydrate & + & $+t+$ \\
\hline $\mathrm{CoCl}_{2}$ & $+t+$ & +++ \\
\hline $\mathrm{CoCl}_{2}+$ chloral hydrate & $++t$ & $++t$ \\
\hline $\mathrm{CoCl}_{2}$, rinse, chloral hydrate & + & $+t+$ \\
\hline Nocodazole & --- & - \\
\hline $\mathrm{CoCl}_{2}+$ nocodazole & --- & - \\
\hline $\begin{array}{l}\mathrm{CoCl}_{2}+\text { chloral hydrate, rinse, } \\
\text { nocodazole }\end{array}$ & + & + \\
\hline \multicolumn{3}{|c|}{$\begin{array}{l}++++ \text {, Nore than normal number; }+++ \text {, normal number; } \\
+ \text {, some; }- \text {, very few; }--- \text {, none. Each treatment was for } \\
10 \text { min. Concentrations: } 0.1 \% \text { chloral hydrate, } 10 \mathrm{~mm}-\mathrm{CoCl}_{2} \text {, } \\
2.5 \mu \mathrm{M} \text {-nocodazole. }\end{array}$} \\
\hline
\end{tabular}

\section{Discussion}

We found that addition of chloral hydrate to PtK cells caused the concentration of intracellular free $\mathrm{Ca}^{2+}$ to rise within $15 \mathrm{~s}$ of application, peaking within a minute at levels two to seven times greater than baseline. The $\mathrm{Ca}^{2+}$ concentration then slowly decreased, but had not returned to basal levels by $12 \mathrm{~min}$. Using tubulin immunofluorescence, we found that a $2-5 \mathrm{~min}$ exposure to chloral hydrate yielded very short metaphase spindles with abnormally long aster microtubules. A $10 \mathrm{~min}$ exposure to chloral hydrate caused both metaphase and anaphase spindles to lose aster and interpolar microtubules, but interphase microtubules were unaffected. Both the spindle shortening and microtubule loss were prevented by treatment with $\mathrm{CoCl}_{2}$. These results suggest that the chloral hydrate-induced shortening of metaphase spindles and the inhibition of anaphase spindle elongation by chloral hydrate are due to sustained high levels of $\mathrm{Ca}^{2+}$. They also indicate that mitotic microtubules are more labile to $\mathrm{Ca}^{2+}$ than interphase microtubules.

The effect of elevated levels of intracellular $\mathrm{Ca}^{2+}$ on mitotic and interphase microtubules in vivo has been studied previously by either injecting $\mathrm{CaCl}_{2}$ into the cell (Kiehart, 1981; Izant, 1983; Keith et al. 1983; Keith, 1987) or by exposing cells to A23187, a Ca ${ }^{2+}$ ionophore (Fuller \& Brinkley, 1976; Huchon \& Ozon, 1985; Keith et al. 1983). In none of the above studies was the difference in $\mathrm{Ca}^{2+}$ lability between interphase and mitotic microtubules compared directly, although $\mathrm{Ca}^{2+}$ concentration was a major factor in inducing microtubule breakdown. Injection of $\mathrm{CaCl}_{2}$ produced rapid but transient breakdown of microtubules in the region of injection, as the cells quickly removed the excess free $\mathrm{Ca}^{2+}$ (Kichart, 1981; Izant, 1983; Keith et al. 1983; Keith, 1987). A23187 produced generalized microtubule breakdown in interphase cells when the external $\mathrm{Ca}^{2+}$ concentration was sufficiently high (Fuller \& Brinkley, 1976; Keith et al. 1983). Our interpretation that the effects of chloral hydrate on mitosis are ria $\mathrm{Ca}^{2+}$ elevation fits well with a conclusion from the above studies, in that an increase in intracellular free $\mathrm{Ca}^{2+}$ is adequate to produce microtubule breakdown in zivo. In addition, the early pattern and timing of microtubule breakdown and spindle shortening in prometaphase PtK cells after injection of either $\mathrm{CaCl}_{2}$ or $\mathrm{Ca}$-calmodulin (Keith, 1987 ) is very similar to that observed in our chloral hydrate-treated metaphase cells. During the $30 \mathrm{~s}$ to $3 \mathrm{~min}$ post-injection time, both kinetochore and interpolar microtubules became shorter, while astral microtubules appeared normal (Keith, 1987). Chloral hydrate-treated cells showed a similar time course ( $\mathrm{sec}$ Fig. 4B,C).

Our results with chloral hydrate are also in agreement with earlier work showing that mitotic microtubules are more labile than interphase microtubules (DeBrabander et al. 1986). Our data extend thesc findings, in that we have found that mitotic microtubules appear to be more $\mathrm{Ca}^{2+}$-labile than interphase microtubules. This needs further work to be certain, since chloral hydrate-treated mitotic cells tended to have high levels of calcium for a slightly longer time than interphase cells (Table 1). Nonetheless, the observation of increased $\mathrm{Ca}^{2+}$ lability of mitotic microtubules is in accord with previous reports. For instance, Saxton et al. (1984) found that in PtK cells most mitotic microtubules turn over more rapidly than interphase microtubules. However, a simple model in which $\mathrm{Ca}^{2+}$ prevents assembly of newly polymerizing microtubules cannot explain the difference in $\mathrm{Ca}^{2+}$ lability, since the half-time for turnover of mitotic microtubules is only $20 \mathrm{~s}$, whereas it is $3-5 \mathrm{~min}$ for interphase microtubules as determined by FRAP analysis (Saxton et al. 1984). Depolymerization of mitotic microtubules in cells exposed to chloral hydrate took at least $7 \mathrm{~min}$, which is considerably longer than the time required for the complete turnover of most spindle microtubules. Furthermore, recovery of metaphase spindle structure after removal of chloral hydrate took longer than $2 \mathrm{~min}$ (data not shown). Therefore, the difference in $\mathrm{Ca}^{2+}$ lability of interphase and metaphase microtubules is probably due to the interaction of $\mathrm{Ca}^{2+}$ with another factor rather than to $\mathrm{Ca}^{2+}$ acting directly on microtubules.

The prevention by $\mathrm{CoCl}_{2}$ of chloral hydratc-induced spindle shortening and microtubule breakdown could occur by two mechanisms. (1) Cobalt ions blocking the influx of $\mathrm{Ca}^{2+}$, as has been shown for muscle cells (Kohlhardt et al. 1973); or (2) cobalt ions entering the cell and binding to microtubules, stabilizing them against $\mathrm{Ca}^{2+}$-induced breakdown. $\mathrm{Co}^{2+}$ has been shown to protect microtubules in vitro against $\mathrm{Ca}^{2+}$ 
and colchicine (Wallin et al. 1977). In our study, $\mathrm{Co}^{2+}$ does not enter normal PtK cells in sufficient quantity to stabilize mitotic microtubules against nocodazole. However, when cells were treated with chloral hydrate in the presence of $\mathrm{CoCl}_{2}, \mathrm{Co}^{2+}$ entered the cell. This is based on three observations. First, when attempting to measure $\mathrm{Ca}^{2+}$ in Fura-2-loaded cells treated with $\mathrm{CoCl}_{2}$ and chloral hydrate, the basal levels were stable and normal in the presence of $\mathrm{Co}^{2+}$, but the fluorescence faded at both wavelengths $1-2$ min after adding chloral hydrate. It was determined that $\mathrm{Co}^{2+}$ quenches Fura-2 fluorescence in vitro (unpublished observations). Second, after treatment with $\mathrm{CoCl}_{2}$ and chloral hydrate, followed by nocodazole, some mitotic microtubules remained (Fig. 7C). Third, the metaphase spindle is larger, with longer asters, in cells treated with $\mathrm{CoCl}_{2}$ and chloral hydrate (Fig. 6C).

The influx of $\mathrm{Co}^{2+}$ induced by chloral hydrate suggests that chloral hydrate is acting on the plasma membrane. There are additional reasons for thinking that the rise in intracellular free $\mathrm{Ca}^{2+}$ produced by chloral hydrate involves an interaction with one or more sites on the plasma membrane. One site of chloral hydrate action is the plasma membrane $\mathrm{Ca}^{2+} / \mathrm{Mg}^{2+}$. ATPase (Bergesse et al. 1983). Other membrane ATPases are also inhibited by chloral hydrate although they are less sensitive than the $\mathrm{Ca}^{2+} / \mathrm{Mg}^{2+}$-ATPase (Bergesse et al. 1983). Our finding that spindle elongation was inhibited when $0 \cdot 1 \%$ chloral hydrate was. applied extracellularly, but not when $7.5 \%$ was injected into the cell, also indicates that chloral hydrate effects are due to an interaction with the plasma membrane, rather than an intracellular site. In addition, in preliminary experiments, we found that $5 \mu \mathrm{M}$ TMB-8, a drug that inhibits $\mathrm{Ca}^{2+}$ release from the endoplasmic reticulum (Malagodi \& Chiou, 1974), did not prevent the rise in $\mathrm{Ca}^{2+}$ levels induced by chloral hydrate. On the other hand, $10 \mathrm{~mm}$-EGTA prevented or greatly reduced the $\mathrm{Ca}^{2+}$ response produced by chloral hydrate. These preliminary findings indicate that the rise in $\mathrm{Ca}^{2+}$ levels caused by chloral hydrate is due to $\mathrm{Ca}^{2+}$ entering the cell and not to $\mathrm{Ca}^{2+}$ being released from intracellular stores.

There is a possibility that the elevated $\mathrm{Ca}^{2+}$ levels have reduced the cell's ATP levels by damaging the mitochondria and thus is not affecting mitosis directly. For example, mitosis completely stops in Xenopus oocytes in which the ATP levels have been depleted to $50 \%$ of normal by carbon monoxide (Epel, 1963). In dinitrophenol/deoxyglucose-treated cells, which have ATP levels reduced to $31 \%$ of normal, saltatory motion and all anaphase movement stops (Spurck et al. 1986), but in chloral hydrate-treated cells saltatory motion, chromosome-to-pole movement and cytokinesis continued normally. So it is unlikely that chloral hydratetreated cells have greatly reduced levels of ATP. It should be noted that the $\mathrm{Ca}^{2+}$ concentration in the above ATP-depleted cells (Epel, 1963; Spurck et al. 1986) was not determined, but a lack of ATP would certainly inhibit the $\mathrm{Ca}^{2+} / \mathrm{Mg}^{2+}$-ATPase.

In summary, we have presented evidence that chloral hydrate increases intracellular $\mathrm{Ca}^{2+}$ levels. The findings, that this rise occurs consistently, that elevations in $\mathrm{Ca}^{2+}$ have previously been shown to alter mitotic spindles in a similar way, and that $\mathrm{Co}^{2+}$ prevents these alterations, argue for elevated $\mathrm{Ca}^{2+}$ being the means by which chloral hydrate produces its effects on mitosis. We have not ruled out the possibility that chloral hydrate has other effects on the cell in addition to elevating $\mathrm{Ca}^{2+}$. However, no other alteration in cell physiology is known to produce the pattern of microtubule breakdown that we have observed.

We thank R. B. Nicklas, in whose laboratory most of this work was done, for support and constructive criticisms. We also thank E. D. Salmon for suggesting the nocodazole experiments. This work was supported by NIH GM-13745 to R.B.N. and by AG07218, AHA 861299 and NC AHA 86-87A.02 to B.H. During this work G.M.L. was supported by NIH training grant no. 5T32GM07184.

\section{References}

ATES, Y. \& SEnTEIN, P. (1978). A comparison between the action of colchicine, chloral hydrate, glutaraldehyde and phenylurethane on the ultrastructure of segmentation mitoses in a newt. Biol. Cell 33, 129-136.

Bergesse, J. R., Domenech, C. E. \& Balegno, H. F. (1983). Chloral hydrate inhibition in vitro of ATPase in membrane of rat erythrocytes and in microsomes of dog kidney external medulla. Biochem. Phamac. 32, 3221-3225.

BERRIDGe, M. J. \& IRvine, R. F. (1984). Inositol trisphosphate, a novel second messenger in cellular signal transduction. Nature, Lond. 312, 315-321.

CARAFOLI, E. (1982). The transport of calcium across the inner membrane of mitochondria. In Membrane Transport of Calcium (ed. E. Carafoli), pp. 107-139. London: Academic Press.

Carafoli, E. \& Penniston, J. T. (1985). The calcium signal. Scient. Am. 253, 70-78.

De Brabander, M., Geuens, G., Nuydens, R., Willebrords, R., Aerts, F., DeMey, J., With the PARTICIPATION OF J. R. MCIntosh. (1986). Microtubule dynamics during the cell cycle: the effects of taxol and nocodazole on the microtubule system of PtK2 cells at different stages of the mitotic cycle. Int. Rev. Cytol. 101, 215-274

De Mey, J., Moeremans, M., Geuens, G., Nuydens, R., Belle, H. V. \& De Brabander, M. (1980). Light- and electron microscopic localization of calmodulin in mitotic PTK2 cells. Eur. \%. Cell Biol. 22, 297 (abstract).

DiGuisepPi, J., Inman, R., Ishihara, A., Jacobson, K. \& Herman, B. (1985). Applications of digitized 
fuorescence microscopy to problems in cell biology. Biotechniques 3, 394-403.

DUNLAP, K. (1977). Localization of calcium channels in Paramecium caudatum. F. Physiol., Lond. 271, 119-133.

EPEL, D. (1963). The effects of carbon monoxide inhibition on ATP level and the rate of mitosis in the sea urchin egg. F. Cell Biol. 17, 315-319.

Fuller, G. M. \& Brinkley, B. R. (1976). Structure and control of assembly of cytoplasmic microtubules in normal and transformed cells. F. supramolec. Struct. 5 497(349)-514(366).

Grynkiewicz, G., Poenie, M. \& Tsien, R. Y. (1985). A new generation of $\mathrm{Ca}^{2+}$ indicators with greatly improved fluorescence properties. Y. biol. Chem. 260, 3440-3450.

HePlek, P. K. (1985). Calcium restriction prolongs metaphase in dividing Tradescantia stamen hair cells. 7. Cell Biol. 100, 1363-1368.

Hepler, P. K. \& Wolniak, S. M. (1984). Membranes in the mitotic apparatus: their structure and function. Int. Rev. Cytol. 90, 169-238.

HuchoN, D. \& OzON, R. (1985). Microtubules during germinal vesicle breakdown of Xenopus laevis oocytes effect of calcium ionophore A-23187, calcimycin and taxol. Reprod. Nutr. Dev. 25, 465-480.

IZANT, J. G. (1983). The role of calcium ions during mitosis: calcium participates in the anaphase trigger. Chromosoma 88, 1-10.

KAFER, E. (1986). Tests which distinguish induced crossing-over and aneuploidy from secondary segregation in Aspergillus treated with chloral hydrate or gammarays. Mutat. Res. 164, 145-166.

KerTH, C. H. (1987). Effect of microinjected calciumcalmodulin on mitosis in PtK2 cells. Cell Motil. Cyloskel. 7, $1-9$.

Keith, C. H., di Paola, M., Mazfield, F. R. \& SHELANSKI, M. L. (1983). Microinjection of $\mathrm{Ca}^{2+}$. calmodulin causes a localized depolymerization of microtubules. Y. Cell Biol. 97, 1918-1924.

KIEHART, D. (1981). Studies on the in vivo sensitivity of spindle microtubules to calcium ions and evidence for a vesicular calcium-sequestering system. Y. Cell Biol. 88, 604-617

Kohlhardt, M., Bauer, B., Krause, H. \& Fleckenstein, A. (1973). Selective inhibition of the transmembrane Ca conductivity of mammalian myocardial fibres by $\mathrm{Ni}, \mathrm{Co}$ and $\mathrm{Mn}$ ions. Pflügers Arch. ges. Physiol. 338, 115-123.

Lemasters, J. J., DiGuiseppi, J., Nieminen, A.-L. \& Herman, B. (1987). Blebbing, free $\mathrm{Ca}^{2+}$ and mitochondrial membrane potential preceding cell death in hepatocytes. Nature, Lond. 325, 78-81.

Lin, S.-H., Wallace, M. A. \& Fain, J. N. (1983). Regulation of $\mathrm{Ca}^{2+}-\mathrm{Mg}^{2+}$-ATPase activity in hepatocyte plasma membranes by vasopressin and phenylephrine. Endocrinology 113, 2268-2275.

Malagod, M. H. \& Chiou, C. Y. (1974). Pharmacological evaluation of a new $\mathrm{Ca}^{2+}$ antagonist, $\beta$ $(N, N$-diethylamino-octyl-3,4,5-trimthoxybenzoate hydrochloride (TMB-8): studies in smooth muscles. Eur. 7. Pharmac. 27, 25-33.
Marcum, J. M., Dedman, J. R., Brinkley, B. R. \& MEANS, A. R. (1978). Control of microtubule assemblydisassembly by calcium-dependent regulator protein. Proc. natm. Acad. Sci. U.S.A. 75, 3771-3775.

Mercer, B. \& Morris, N. R. (1975). The effect of chloral hydrate upon mitosis in Aspergillus nidulans. Y. gen. Microbiol. 88, 197-199.

Mole-Bajer, J. (1967). Chromosome movements in chloral hydrate treated endosperm cells in zitro. (hromosoma 22, 465-480.

OsBorn, M. \& Weber, K. (1982). Immunofluorescence and immunocytochemical procedures with affinity purified antibodies: tubulin-containing structures. Meth. Cell Biol. 24, 97-132.

Pershadsingh, H. A. \& McDonald, J. M. (1981). (Ca ${ }^{2+}$. $\mathrm{Mg}^{2+}$ )-ATPase in adipocyte plasmalemma: inhibition by insulin and Concanavalin $A$ in the intact cell. Biochem. Int. 2, 243-248.

Poenie, M., Alderton, J., Steinhardt, R. \& T'sien, R. (1986). Calcium rises abruptly and briefly throughout the cell at the onset of anaphase. Science 233, 886-889.

Poenie, M., Alderton, J., Tsien, R. Y. \& Steinhardt, R. A. (1985). Changes of free calcium levels with stages of the cell division cycle. Nature, Lond. 315, 147-149.

RAPPAPORT, R. (1986). Simple methods and devices for handling echinoderm eggs. Meth. Cell Biol. 27, 345-358.

Ratan, R. R., Shelanski, M. L. \& Maxfield, F. R. (1986). Transition from metaphase to anaphase is accompanied by local changes in cytoplasmic frec calcium in PtK $\mathrm{P}_{2}$ kidney epithelial cells. Proc. maln. Acad. Sci. U.S.A. 83, 5136-5140.

Rebhun, L. I., Jemiolo, D., Keller, T., Burgess, W. \& Kretsinger, R. (1980). Calcium, calmodulin and control of assembly of brain and spindle microtubules. In Microtubules and Microtubule Inhibitors (ed. N. De Brabander \& J. De Mey), pp. 243-252. Amsterdam: Elsevier/North-Holland Biomedical Press.

Ris, H. (1949). The anaphase movement of chromosomes in the spermatocytes of the grasshopper. Biol. Bull. mar. biol. Lab., Woods Hole 96, 90-106.

Roe, M. W., Lemasters, J. J. \& Herman, B. (1987). An assessment of the use of Fura-2 for the determination of intracellular calcium concentration. Fedn Proc. Fedn $\mathrm{lm}$. Socs exp. Biol. 46, 2277.

Russo, A., Pacchierotti, F. \& Metall., P. (1984). Nondisjunction induced in mouse spermatogenesis by chloral hydrate, a metabolite of trichloroethylene. Encir: Mutagen. 6, 695-703.

Salmon, E. D. (1982). Calcium, spindle microtubule dynamics and chromosome movement. Cell Differ. 11, 353-355

Salmon, E. D. \& SEgall, R. R. (1980). Calcium-labile mitotic spindles isolated from sea urchin eggs (Lytechimus variegatus). \%. Cell Biol. 86, 355-365.

Saxton, W. M., Stemple, D. L., Leslie, R. J., Salmon, E. D., Zavortink, M. \& McIntosh, J. R. (1984).

Tubulin dynamics in cultured mammalian cells. . . Cell Biol. 99, 2175-2186.

SchatzmanN, H. J. (1982). The plasma membrane calcium pump of erythrocyte and other animal cells. In 
Membrane Transport of Calcium (ed. E. Carafoli), pp. 41-108. London: Academic Press.

Spurck, T. P., Picketr-Heaps, J. D. \& Klymkowsky, M. W. (1986). Metabolic inhibitors and mitosis: I. Effects of dinitrophenol/deoxyglucose and nocodazole on the live spindle. Protoplasma 131, 47-59.

Vantard, M., Lambert, A.-M., DeMey, J., Piceuot, P. \& VAN ELDIK, L. J. (1985). Characterization and immunocytochemical distribution of calmodulin in higher plant endosperm cells: localization in the mitotic apparatus. J. Cell Biol. 101, 488-499.

VASSORT, G., WhitTEMBURY, J. \& Nullins, L. J. (1986). Increases in internal $\mathrm{Ca}^{2+}$ and decreases in internal $\mathrm{H}^{+}$ are induced by general anesthetics in squid axoms. Biophys. Y. 50, 11-19.

Wallin, M., Larsson, H. \& Edstrom, A. (1977).

Tubulin sulfhydryl groups and polymerization in vitro. Effects of di- and trivalent cations. Expl Cell Res. 107, 219-225.

Wier, W. G., Cannell, M. B., Berlin, J. R., Marban, E. \& Lederer, W. J. (1987). Cellular and subcellular heterogeneity of $\left[\mathrm{Ca}^{2+}\right]_{i}$ in single heart cells revealed by Fura-2. Science 235, 325-328.

(Receired 7 July 1987 - Accepted 7 September 1987) 